\title{
Single Stapling of Right Upper Lobe Vein and Truncus Anterior Artery in Videothoracoscopic Lobectomy
}

\author{
Videotorakoskopik Lobektomide Sağ Üst Lob Veni ve \\ Truncus Anterior Arterinin Divizyonunda Tek Stapler \\ Kullanımı
}

Olgu Sunumu

Case Report

Received/Geliş: 27.11.2019 Accepted/Kabul: 27.11.2019 Published Online: 18.08 .2021

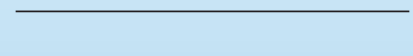

ilker Kolbas

Sultan Abdülhamid Han Eğitim ve Araştırma Hastanesi, Gögüs Cerrahisi Kliniği, Istanbul - Türkiye dr_ilkerkolbas@hotmail.com ORCID: 0000-0003-1656-9595

Ç. Tezel 0000-0001-5272-6215

S. Evman 0000-0002-1672-966X V. Baysungur 0000-0003-1053-1051 Süreyyapaşa Gögüs Hastalıkları ve Gögüs Cerrahisi Eğitim ve Araştırma Hastanesi, Göğüs Cerrahisi Kliniği, Istanbul - Türkiye

T. Doğruyol 0000-0003-0875-8409 Manisa Devlet Hastanesi, Göğüs Cerrahisi Kliniği, Manisa - Türkiye

M Akyıl 0000-0001-6986-2651 Çanakkale Devlet Hastanesi, Göğüs Cerrahisi Kliniği, Çanakkale - Türkiye

Cite as: Kolbas i, Tezel Ç, Doğruyol T, Akyıl M, Evman S, Baysungur V. Single stapling of right upper lobe vein and truncus anterior artery in upper lobe vein and truncus anterior artery in videothoracoscopic lobectomy. Tepecik Egit. ve Araşt. Hast. Dergisi. 2021;31(2):288-90.

\author{
Illker Kolbas $\odot$, Çağatay Tezel $\odot$, Talha Doğruyol $\odot$, Mustafa Akyıl $\odot$, Serdar Evman $\odot$ \\ Volkan Baysungur $\odot$
}

\begin{abstract}
Videothoracoscopic resections are among the mostly preferred minimally invasive thoracic surgical techniques to treat lung cancers especially in the last two decades. In thoracoscopic surgery video camera technology, high-tech equipment and surgical instruments including staplers are required. We have developed a technique for dissection and cutting of truncus anterior and right upper lobe vein in one step with stapler by this way we aimed to provide less operation time and more cost- effectiveness for right upper lobectomies.
\end{abstract}

Keywords: Videothoracoscopic resections, minimally invasive surgery, right upper lobectomy

öz

Videotorakoskopik rezeksiyonlar, özellikle son yirmi yılda akciğer kanseri tedavisine en çok tercih edilen minimal invaziv cerrahi tekniktir. Torakoskopik cerrahide video kamera teknolojisi, teknolojik ekipman ve staplerler gibi yüksek teknoloji cerrahi aletler gereklidir. Truncus anterior ve sağ üst lob veninin tek seferde stapler ile kesilmesi için bir teknik geliştirdik, bu şekilde sağ üst lobektomiler için daha az operasyon süresi ve daha düşük maliyet etkinliği sağlamayı amaçladık.

Anahtar kelimeler: Videotorakoskopik rezeksiyon, minimal invaziv cerrahi, sağ üst lobektomi

\section{INTRODUCTION}

Long-term

outcomes

of videothoracoscopic resection surgery for early- stage lung cancer have shown good results comparable to resections with thoracotomy. So that thoracic surgeons have begun to take on performing their best to minimize effects of surgery, so as to improve the quality of life ${ }^{(1,2)}$.

\section{CASES}

We have performed videothoracoscopic right upper lobectomy for 6 patients. Non-small cell lung cancer was diagnosed in all patients. Consecutive six patients with right upper lobe tumors underwent videothoracoscopic was $60 \pm 13$. We used 2 ports as our standard management in all cases. Anterior incisions were preferred in our all videothoracoscopic procedures. One $45 \mathrm{~mm}$ Endo GiaTM staplers were used for cutting both upper lobe pulmonary vein and truncus anterior artery. Mean duration of operations were $70 \pm 38$ minutes. There were no peroperative lobectomy. Mean age of the patients

(C) Telif hakkı TC. Să̆lık Bakanlı̆̆ı izmir Tepecik Eğit. ve Arastt. Hastanesi. Logos Tip Yayınclık tarafindan yayınlanmaktadır. Bu dergide yayınlanan bütün makaleler Creative Commons Atff-GayriTicari 4.0 Uluslararası Lisansı ile lisanslanmıştır.

(c) Copyright Association of Publication of the T.C. Ministry of Health Izmir Tepecik Education and Research Hospital.

This journal published by Logos Medical Publishing.

Licenced by Creative Commons Attribution-NonCommercial 4.0 International (CC BY) 


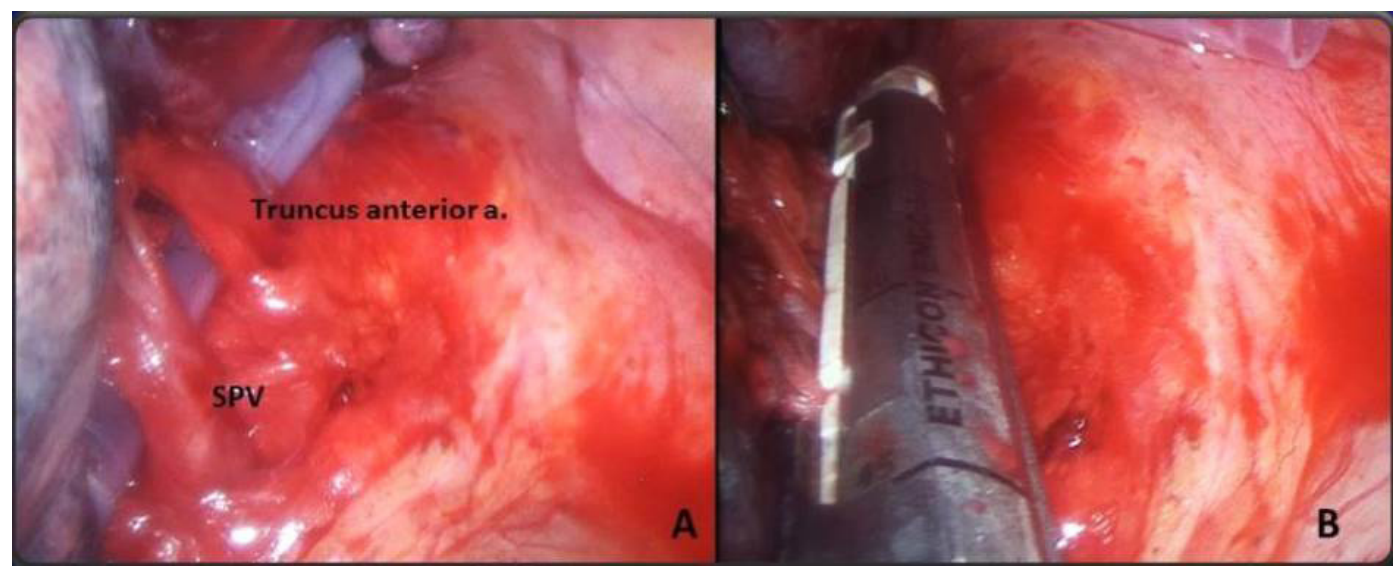

Figure 1. Single stapling technique of right upper lobe vein and truncus anterior artery during videothoracoscopic lobectomy.

(A) Right upper lobe vein and Truncus anterior artery have been dissected

(B) Both vascular structures in a single stapler

complication. In this article we aimed to show that technically it's possible to staple both truncus anterior branch of pulmonary artery and pulmonary vein of the upper lobe just in one step.

\section{DISCUSSION}

Patients were intubated with standard double- lumen tube and laid in lateral decubitus position. An almost $2 \mathrm{~cm}$-long incisions were made for the thoracoscope to be inserted through the seventh intercostal space in the midaxillary line. A second $4 \mathrm{~cm}$-long incision was made for large instruments to be inserted through the fourth intercostal space in the anterior axillary line. Then a meticulous and complete intrathoracic exploration including tumor and whole parenchyma were performed. Adhesions in thoracic cavity were cut with ultrasonic scalpel Harmonic Ace (Ethicon Endo-Surgery Inc, Blue Ash, OH, USA). After decision of performing lobectomy, right upper lobe veins were dissected at first. By pulling the right upper lobe backward, the anterior hilar was exposed. The vein was dissected and dissociated carefully from surrounding tissues including vascular sheath. We always try to observe lower vein at this step. Although usually cutting of upper lobe pulmonary vein is preferred initially, we dissected truncus anterior behind the vein. After dissection of both of upper lobe pulmonary vein and truncus anterior, we stapled both them with one $45 \mathrm{~mm}$ Endo GiaTM vascular stapler (Figure 1). Then bronchial dissection and stapling were performed with $60 \mathrm{~mm}$ vascular stapler as usual. Posterior ascending artery either can be ligated with heamolock or stapled. The resected lobe is removed with endobag. After systemic lymph node dissection, a deep exploration is performed to rule out the possibility of bleeding or air leak. During the procedure, no complication was observed. We usually prefer to insert two chest tubes.

The mean duration of the operations was $70 \pm 38$ minutes and amount of operative drainage was 50-150 cc. These results are comparable with our other VATS lobectomy series ${ }^{(6)}$. Postoperative period was uneventful.

Many centers usually don't prefer performing videothoracoscopic lobectomy for right upper lobes during their learning curves due to anatomical and technical difficulties as there are more vessels to dissect $^{(3)}$. Another clue for VATS lobectomies is being accustomed to performing anterior exposures ${ }^{(4)}$. Pulmonary vein of the upper lobe should be divided first because superior branches of pulmonary vein partly hide the truncus anterior artery ${ }^{(5)}$. Truncus anterior artery and its two branches (apicoposterior and anterior branches) are only visible after the dissection of pulmonary vein of the upper lobe. 


\section{CONCLUSIONS}

We prefer using anterior incisions during videothoracoscopic lobectomy in our clinic based on our ten years of clinical experience. We have developed a technique to staple truncus anterior and superior pulmonary vein with one $45 \mathrm{~mm}$ Endo GiaTM endovasculer stapler during videothoracoscopic lobectomy that is comfortably feasible with anterior exposure. We observed that using this procedure can shorten operative times with more cost- effectiveness.

Conflict of Interest: We have no conflict of interest. Informed Consent: Not required.

\section{REFERENCES}

1. Han DP, Xiang J, Li HC, Hang JB. Uniportal video-assisted thoracic surgery right upper lobectomy with systemic lymphadenectomy. J Thorac Dis 2016;8:2272-74. [CrossRef]

2. Bendixen $M$, Jergensen $O D$, Kronborg $C$, Andersen $C$, Licht PB. Postoperative pain and quality of life after lobectomy via video-assisted thoracoscopic surgery or anterolateral thoracotomy for early stage lung cancer: a randomised controlled trial. Lancet Oncol 2016;17:836-44. [CrossRef]

3. Petersen $\mathrm{RH}$, Hansen $\mathrm{HJ}$. Learning curve associated with VATS lobectomy. Ann Cardiothorac Surg 2012;1:47-50.

4. Gonzalez-Rivas D, Fieira E, Delgado M, Mendez L, Fernandez $\mathrm{R}$, de la Torre $\mathrm{M}$. Uniportal video-assisted thoracoscopic lobectomy. J Thorac Dis 2013;5:234-45.

5. Gossot D, Ramos R, Brian E. Thoracoscopic pulmonary anatomical segmentectomies. In: Inderbitzi RGC, Schmid RA, Melfi FMA, Casula RP eds. Minimally Invasive Thoracic and Cardiac Surgery: Textbook and Atlas. Berlin,Heidelberg; Springer, 2012:113-35. [CrossRef]

6. Cosgun T, Baysungur V, Tezel C, Alpay L, Okur E, Kutlu CA et al. Learning and improvement process of video-assisted thoracoscopic lobectomy: experiences of Sureyyapasa. Turk Gogus Kalp Dama 2014;22:589-95. [CrossRef] 